\title{
Challenges of Risk Management in Credit Card Transactions in Sri Lanka
}

\author{
By \\ Anil Ravindra Waidyalankara \\ Deputy Inspector General of Police \\ Sri Lanka.
}

Thesis submitted to the University of Sri Jayewardenepura for the award of the Master of Philosophy in "Criminology" in Sri Lanka on 11.04.2013. 


\section{Declaration of the Researcher}

This Research contains no material which has been accepted for the award of any other Degree of Diploma in any University of equivalent Institution, and that to the best of my knowledge and belief, contains no material previously submitted or written by any other person, except where due reference is made in the text of this dissertation/research paper.

I carried out the work described in this Research under the supervision of Mr. W.M. Dhanapala, Senior Lecturer, Department of Sociology and Anthropology of the University of Sri Jayewardenepura, Sri Lanka.

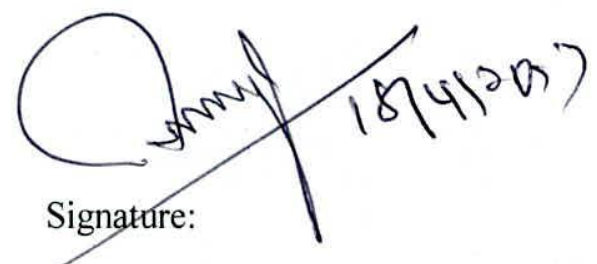




\section{Declaration of the Supervisor}

This is to certify that I, W.M. Dhanapala, Senior Lecturer of the Department of Sociology and Anthropology of the University of Sri Jayewardenepura, Sri Lanka, supervised the research, conducted by the student, Reg. No. GS/M.PHill/CRZ/3112/07, titled as "Challenges of Risk Management in Credit Cards Transactions in Sri Lanka."

I recommend this thesis as eligible to be forwarded to the University of Sri Jayewardenepura for assessment and evaluation.

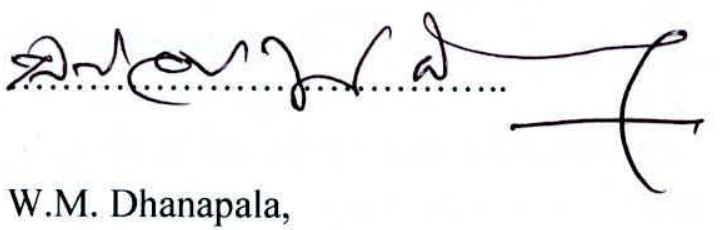

Senior Lecturer, Department of Sociology and Anthropology,

University of Sri Jayewardenepura, Sri Lanka. 


\section{Viva - Voce Examination M.Phil Degree - A.R. Widyalankara}

This is to certify that, all minor corrections, additions and amendments, pointed out at the Vive-Voce Examination of the thesis report submitted by A.R. Waidyalankara (Student No GS/M.Phil/CRZ/3112/07) have been properly done in accordance with the comments and suggestions made by examiners.

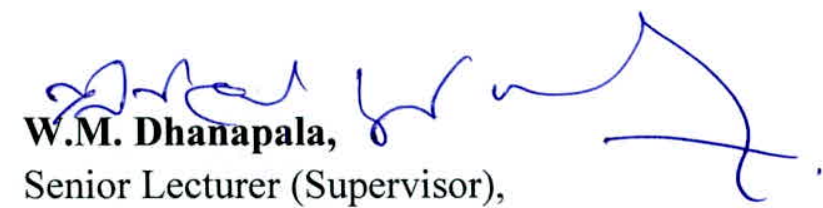

Department of Sociology and Anthropology, University of Sri Jayewardenepura, Sri Lanka.

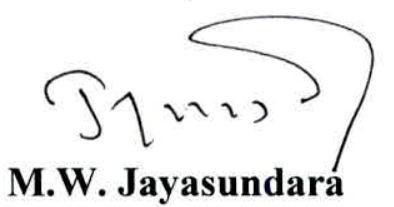

Head of the Department,

Department of Sociology and Anthropology, University of Sri Jayewardenepura, Sri Lanka.

11.04.2013 


\section{$\underline{\text { Acknowledgment }}$}

I wish to express my sincere gratitude to my supervisor, Mr. W.M. Dhanapala, Senior Lecturer, of the Department of sociology and Anthropology University of Sri Jayewardenepura, Sri Lanka for excellent guidance and advice, the encouragement and the support given to me during the period of my endeavor to complete this research work. I wish to thank Mr. Raja Gunaratne, The Senior Lecturer of the Open University of Sri Lanka for the valuable in-sight given at the seminars conducted by me. I also thank the Course coordinators and their staff and all faculty members for facilitating from the very inception.

I am gratitude to all personnel of the Criminal Investigation Department and the National Intelligence Service for providing me with sensitive and classified details on frauds on credit cards and national security access. The Senior Executives of the VISA International and Commercial Bank authorize to issue Credit cards and the Officials of the Central Bank of Sri Lanka, provided me with invaluable data for my research, I thank all of them.

I express my sincere gratitude to all my dear ones and the family along with my stenographers who were assisted me in many ways to complete the research without hardship. 


\title{
Challenges of risk management in Credit Card Transaction \\ in Sri Lanka
}

By

\section{Anil Ravindra Waidyalankara}

\begin{abstract}
The problem examine in this research is "Challenges of Risk Management in Credit Cards Transaction in Sri Lanka". The concept of money has been generated and introduced to the human civilization owing to the trade and businesses conducted as a medium of exchange of value of the product, whether it's goods or services. With the expansion of trade within the countries and offshore the country faced with numerous issues in exchanging money due to the volume, the nature and the security of physical money. Physical money begins with pieces of metal, coins and developed to paper money with lot of security features. With the advent of technology, the concept of paper money developed to plastics overriding the fear of carrying huge volume of physical money and its security.
\end{abstract}

The concept of plastic money evolves with the technological advancement without any physical money. The value of currency of the particular trade will be transferred from the Credit of the buyer or the beneficiary through the cyber space. This operation is being facilitated by the credit card service providers such as VISA and Master cards. The Credit limit is encrypted in the magnetic script or the micro chip and the transactions are permitted according to the credit limit and facilitated by the technology over cyber space. 
The transformation of money from metal to paper and paper to plastics created a new paradigm in the world of business. Along with the transformation the component of the risk also considerably increased due to certain vulnerabilities. Since the technology is the key in credit card business, less IT literary societies faced with numerous Challenges and monetary loses with higher degree of risk. It is mainly due to the arrival of the concept of credit cards without proper IT literacy, institutional frame work, infrastructure and legal safeguards. It is worth to note the use of credit are very much popular in the West and expeditiously developed to the other jurisdictions mainly due to international trading and travel. Although adequate legal and institutional infrastructure backed with IT had overcome most of the Challenges prevailed in the West, the under-developed countries are being faced with numerous challenges of controlling the degree of risk.

Sri Lanka is one country where the operations of the Credit cards commence in decade ago. According to the Annual Report of the Central Bank, issued in 2010 nearly 778,549 are circulating in Sri Lanka issued by the 11 Commercial Banks. There are only 58,771 are meant to local consumption and the balance 719,678 are being provided to use locally and internationally. Further it is worth to note that the volume of trade conducted utilizing the Credit cards are on the rise in Sri Lanka. With the accumulation the risk faced by the Banks merchants and the customers also gradually raises without adequate security networks.

With the development it has become necessary to manage the risk of Credit currency in the Sri Lankan way. It is need to be identified and gaps have to be filled and the problem should be solved to overcome these issues. The research work is based on with the 
objective of identifying the Challenges and to forward recommendations to the authorities as a food for thought in their strategic planning.

The research objectives are based on four main areas such as:

01. To explain the role and the risk of the credit cards in the modern economy and the society.

2. To ascertain the credit cards related issues and Challenges including the credit cards related fraudulent acts and the investigations.

3. To explore the use of an expansion of credit cards in Sri Lanka.

4. To critically analyze the criminal justice system in Sri Lanka in respect of Credit cards.

Thus, the main concern of the study were focused to identify the role of the credits in modern economy it's nature and scope along with the risk factor emanates, to the economies of the respective countries especially in the, specially to Sri Lanka. It's analyze the judicial systems institutional safeguard remedies and prevention of abuse.

A literary survey was carried out examining and analyzing the international convention legislations of the other countries and anticipated future trends. Due to the fast development of IT, managing risk of Credit cards had become more convenient to the perpetrators. There are large organized groups are in existence in the world to siphon out money or tainted money. Thus, it is imperative to focus attention on the areas of international cooperation, 
mutual assistance and the expeditious development of IT in critically analyzing the existing local legislation.

A significant revelation was surfaced in this study concerning the National Security of Sri Lanka. Certain case studies and in-depth analysis of the antecedents of suspects involved revealed that these groups are utilizing the funds to support and harness terrorism in Sri Lanka and abroad. Directly between the proscribed LTTE and the perpetrators had been revealed. This clearly indicates that the gaps in the business had been clearly identified by the terrorists has made use of it as a source of funding to terrorism. This may be the first ever research conducted in Sri Lanka and uncovered the National Security factor and the influence of the terrorism on the increased risk component of the Credit card management.

The study recommends measure to minimize the perceive challenges and to improve the effectiveness of the Credit card risk management in Sri Lanka. The bottom lines of these recommendations are aimed at achieving the total quality Credit cards risk management regime in Sri Lanka with zero crime and zero delay. 


\section{CONTENTS}

PAGE

Acknowledgement

Abstract

\section{CHAPTER ONE}

\section{INTRODUCTION AND METHODOLOGY}

1.1 Introduction 1

1.2 Significance of the research 2

1.3 Background and research problem 5

1.4 Research objectives 7

1.5 Research method and approach 9

$\begin{array}{lll}1.6 & \text { Data Analysis } & 12\end{array}$

$\begin{array}{lll}1.7 & \text { Scope and limitations of the study } & 12\end{array}$

$\begin{array}{lll}\text { 1.7.1 Limitations of Secondary Data } & 13\end{array}$

$\begin{array}{lll}\text { 1.7.2 Limitations of Primary Data Collection } & 13\end{array}$

$\begin{array}{lll}1.8 & \text { Research Structure } & 13\end{array}$

CHAPTER TWO

\section{LITERATURE REVIEW}

$\begin{array}{lll}2.1 & \text { Introduction } & 15\end{array}$

2.2 Use of credit cards and theoretical models of credit card 15

$\begin{array}{ll}2.3 & \text { Credit card ownership and usage practices } \\ \end{array}$

2.3.1 Issue of E-Payment in India- Consumer concerns 29

2.4 Electronic cash and the virtual market place: Reflections on a 30 revolution postponed

2.5 Credit Card frauds 32

2.6 Requirement of an expert system for monitoring 37

$\begin{array}{lll}2.7 & \text { Data mining for credit card fraud } & 38\end{array}$

$2.8 \quad$ Necessity of specific laws 39

$2.9 \quad$ Fraud dynamics in the card payments transaction 40

2.10 The role of IT in combating fraud 42

2.11 Consumer credit risk assessment 43 
2.12 Public policy 44

2.13 Credit card clarity: card act reform works 44

2.14 Projection of consumer rights 45

2.15 Sociological theories and concept related to credit cards frauds $\quad 47$

\section{CHAPTER THREE}

\section{DIGITAL MONEY EVALUATION, SCOPE \& NATURE}

3.1 Introduction 51

3.2 History of money and Digital Money 51

3.2.1 Money 51

3.2.2 History of Digital Money $\quad 52$

3.3 Types of Digital Cards $\quad 54$

3.3.1 Credit Cards $\quad 54$

3.3.2 Debit Cards 56

3.3.3 Travel and Entertainment (T \& E) Card 56

$\begin{array}{lll}3.3 .4 & \text { Cheque Card } & 57\end{array}$

$\begin{array}{lll}\text { 3.3.5 The Eurocheque Card } & 58\end{array}$

3.3.6 Automated Teller Machine (ATM) Cards $\quad 59$

$\begin{array}{lll}3.3 .7 & \text { Smart Cards } & 62\end{array}$

$\begin{array}{lll}3.3 .8 & \text { Charge Cards } & 63\end{array}$

3.4 Credit Card Industry $\quad 64$

3.4.1 Evolvement of Credit Card Industry 64

3.4.2 Closed Loop System $\quad 65$

3.4.3 Bank Card Associations 66

3.4.4 Credit card processing evolves $\quad 66$

3.4.5 The Functioning of Credit Card Networks -Models of Credit 67

$\begin{array}{lll} & \text { Cards } & \\ 3.4 .6 & \text { Credit Card Transaction } & 70 \\ 3.4 .7 & \text { Grace period } & 77\end{array}$

$\begin{array}{lll}3.4 .8 & \text { Summary of Transaction steps } & 77\end{array}$

$\begin{array}{lll}3.4 .9 & \text { Benefits of Credit cards } & 81\end{array}$

3.4.10 Negative Effects of Credit Cards 83

- $\quad$ Credit Card Fee $\quad 84$ 
- $\quad$ Overspending \& Impulse Buys $\quad 84$

- Poor Credit Ratings 85

- Keep Credit Card Spending in Check 85

- Inflated Pricing for all consumers 85

- Costs to merchants 86

\section{CHAPTER FOUR}

\section{RISK MANAGEMENT}

$\begin{array}{lll}4.1 & \text { Introduction } & 87\end{array}$

$\begin{array}{lll}4.2 & \text { Risk Management } & 87\end{array}$

4.3 Legal and Regulatory - An Overview 90

$\begin{array}{lll}\text { 4.3.1 Contractual relationship } & 91\end{array}$

4.3.2 Essentials of a contract 91

4.3.3 Card Holder Agreement 96

4.3.4 Applicability of the Rules and Regulations 98

4.3.5 Utilization of the Card 98

$\begin{array}{lll}\text { 4.3.6 Use of the Card } & 100\end{array}$

$\begin{array}{lll}\text { 4.3.7 } & \text { Charges } & 103\end{array}$

$\begin{array}{lll}\text { 4.3.8 } & \text { Transaction Instructions } & 105\end{array}$

$\begin{array}{ll}\text { 4.3.9 Quality of Goods and Services } & 106\end{array}$

$\begin{array}{ll}\text { 4.3.10 Exclusion of Liability } & 107\end{array}$

$\begin{array}{lll}\text { 4.3.11 Disclosure of Information } & 108\end{array}$

$\begin{array}{ll}\text { 4.3.12 Lost Card Liability } & 108\end{array}$

$\begin{array}{lll}\text { 4.3.13 Payment } & 110\end{array}$

$\begin{array}{ll}4.4 & 112\end{array}$

$\begin{array}{ll}4.5 \text { Technology } & 112\end{array}$

$\begin{array}{lll}4.6 & \text { Product Management } & 113\end{array}$

$\begin{array}{lll}4.7 & \text { Credit Operations } & 115\end{array}$

$\begin{array}{lll}4.8 & \text { Collection Operations } & 116\end{array}$

$\begin{array}{lll}4.9 & \text { Fraud operation } & 122\end{array}$

$\begin{array}{lll}4.9 .1 & \text { Credit card related offences } & 122\end{array}$

$\begin{array}{lll}4.9 .2 & \text { Types of Frauds } & 124\end{array}$ 
4.10 Risk Faced By Credit Card Industry 131

$\begin{array}{lll}4.11 & \text { Fraud Control } & 134\end{array}$

\section{CHAPTER FIVE}

THE STATUS OF RISK EXISTING IN SRI LANKA

$\begin{array}{lll}5.1 & 142\end{array}$

$\begin{array}{ll}\text { 5.2 The use of Credit Cards in Sri Lanka } & 142\end{array}$

5.3 Types of Cards Issued by Commercial Banks in Sri Lanka 145

$\begin{array}{lll}5.4 & \text { Quantification of monitory losses } & 146\end{array}$

5.5 Fraud trends in Sri Lanka: Statistics of visa international 148

$\begin{array}{lll}\text { 5.5.1 Issuing fraud trends } & 148\end{array}$

$\begin{array}{ll}\text { 5.5.2 Acquiring fraud Trends } & 149\end{array}$

$\begin{array}{lll}5.6 & \text { Significant case studies in Sri Lanka } & 150\end{array}$

5.6.1 Cases of Sri Lanka, with international reference to credit Card 150 Fraud

$\begin{array}{lll}5.7 & \text { The Liberation Tigers of Tamil Eelam (LTTE) } & 154\end{array}$

5.7.1 Cases of Credit Card Frauds in Thailand carried out by LTTE 154

5.7.2 Cases of Credit Card Frauds in Sri Lanka carried out by LTTE 155

$\begin{array}{lll}\text { 5.7.3 Melbourne hit by ID crime with LTTE links } & 155\end{array}$

\section{CHAPTER SIX}

STATUTARY SAFE GUARD ON FRAUD RELATED CREDIT CARD TRANSACTIONS IN UNITED KINGDOM, INDIA, MALAYSIA \& SRI LANKA - COMPARATIVE ANALYSIS

$\begin{array}{llr}6.1 & 159\end{array}$

$\begin{array}{lll}\text { 6.2 Credit Card fraud Related Laws in World } & 160\end{array}$

6.2.1 Credit Card fraud Related Laws in United Kingdom 160

6.2.2 Credit Card fraud Related Laws in United Status of America 172

$\begin{array}{lll}\text { 6.2.3 Credit Card fraud Related Laws in India } & 179\end{array}$

$\begin{array}{lll}\text { 6.2.4 Credit Card fraud Related Laws in Malaysia } & 182\end{array}$

6.2.5 Legal background for credit card frauds in Sri Lanka 192

6.2.6 Statutory Safeguards on Payment Devices Frauds 200 


\section{CHAPTER SEVEN}

DICUSSION \& DATA ANALYSIS

7.1 Discussion on the Change of Paradigm of Money 213

$\begin{array}{ll}7.2 & \text { Managing risk of credit card transaction } \\ & 214\end{array}$

7.2.1 Discussion on Managing risk by acquiring and issuing (Banks) 215

$\begin{array}{lll}7.3 & \text { Risk management } & 222\end{array}$

$\begin{array}{lll}\text { 7.3.1 Assessing risks } & 223\end{array}$

7.3.2 Managing and controlling risks 224

7.4 Issues \& challenges of managing risks in credit cards frauds in Sri 227

7.4.1 Organizational and Governance Issues 228

7.4.2 Uncertainty of Regulatory Environment 229

$\begin{array}{lll}\text { 7.4.3 Increased sophistication of fraudsters } & 229\end{array}$

7.4.4 Challenge of Finding Expertise of Risk Managers 229

$\begin{array}{ll}\text { 7.4.5 Introduction of new payment technology } & 229\end{array}$

$\begin{array}{lll}7.5 & \text { Sri Lanka's Specific Conditions } & 233\end{array}$

7.5.1 Effect on the Social Behavior Pattern 233

$\begin{array}{lll}\text { 7.5.2 Risk Based Laws and Regulations } & 234\end{array}$

7.5.3 Competition among Service Providers 235

$\begin{array}{lll}7.6 & \text { Threat to National Security } 236\end{array}$

7.7 Analysis of the Existing Criminal Justice System 237

\section{CHAPTER EIGHT}

\section{CONCLUTIONS AND RECOMMENDATIONS}

$\begin{array}{lll}8.1 & \text { Introduction } & 240\end{array}$

8.2 Review of the research 240

8.2.1 Identified issues and challenges of credit card frauds in Sri Lanka 242

8.3 Conclusion of the study 243

$\begin{array}{lll}8.4 & \text { Recommendations } & 244\end{array}$

$\begin{array}{ll}\text { BIBIOGRAPHY } & 253\end{array}$ 


\section{FIGURES}

$\begin{array}{lll}\text { Figure:1.1 Methodology } & 10\end{array}$

Figure:1.2 Overall structure of the primary data collection 11

$\begin{array}{lll}\text { Figure: } 3.1 \text { Bilateral model } & 67\end{array}$

Figure: 3.2 Closed-Loop Card Association 68

Figure: 3.3 Multiple Card issuer model 69

Figure: 3.4 Payment by Credit Card $\quad 71$

Figure: 4.1 A diagram of the primary components of Risk Management 88

$\begin{array}{lll}\text { Figure: } 5.1 \text { Credit Card usage locally acceptable } & 143\end{array}$

Figure: 5.2 Credit Card usage both Foreign \& Locally acceptable 144

$\begin{array}{lll}\text { Figure: } 5.3 \text { Total Credit Card usage }-2001-2007 & 145\end{array}$

Figure: 5.4 Credit Card operations by licensed Commercial Bank 147

$\begin{array}{lll}\text { Figure: } 6.1 \text { Credit Card fraud } & 161\end{array}$

$\begin{array}{lll}\text { Figure: } 7.1 & \text { Payment risk } & 215\end{array}$

\section{TABLES}

Table: $3.1 \quad$ Benefits and costs for participant of the Credit Cards 79-81

Table: 6.1 Trend of fraud categories in UK for 2000-2001 160

\section{APPENDIX}

Append: A Issuing- Frauds Trends (Sri Lanka) 265-281

Append: B Acquiring- Frauds Trends (Sri Lanka) 282-298

Append: C Melbourne Hit by ID crime with LTTE links 299

$\begin{array}{lll}\text { Append: D List of Respondents } & 300\end{array}$ 